
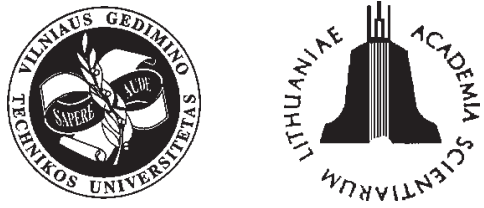

\title{
IN-SITU INVESTIGATION OF CONCENTRATION OF STRAINS AROUND AN IMPLANTED BAR
}

\author{
Valerijus Keras $^{1}$, Jonas Roličius ${ }^{2}$ \\ ${ }^{1}$ Dept of Building Structures, Kaunas University of Technology, Studentu g. 48, LT-51367 Kaunas, Lithuania \\ ${ }^{2}$ Dept of Civil Engineering, University of Šiauliai, Vilniaus g. 141, LT-76353 Šiauliai, Lithuania. \\ E-mail: joro@tf.su.lt
}

Received 29 June 2004; accepted 05 Nov 2004

\begin{abstract}
For constructional purposes reinforcement bars or connecting elements (implants) of a stronger material are installed in concrete, plastic, timber or another similar material-matrix. Structural concepts are being developed where implants are used both as reinforcing and connecting elements. The implants increase the strength and rigidity of structures. However, investigation of functioning of implants and generalisation of data obtained up to now have been premature. Moreover, they do not help us to understand some empiric facts. In the course of the above-mentioned tests (data concerning the tests were presented in previously published works), steel bars-implants with one meter thread were screwed and glued into timber and then attempts to extract them were made. During the test, the bars were screwed into holes in the timber filled with glue. The angle at which the implant was screwed through the layers of wood, the type of glue and some other factors were changed. Such characteristics as strength, strain, breakage and the process of deformation were analysed.
\end{abstract}

Keywords: timber, implants, glue, glulam, strength, strain, breakage failure.

\section{Introduction}

Use of glulams gave an impetus to renaissance of applying this limited-size building material in modern construction [1-3]. Therefore research of glulams is carried out to a great extent [4-7]. Data concerning the peculiarities of their functioning have been acccumulated when structures [7-9] or their knots [10, 11] are exposed to static [8-11] and dynamic [12] short- and long duration [6-8] effects. The data were extended by including investigation in mechanics of parts under strain $[13,14]$, new trends and concepts [14-16], new attitudes $[16,17]$ concerning design standards of timber structures [18-20]. More consideration was given to elements strengthening structures [21], eg reinforcing [22, 23], glued-in metal implants [16, 22-24], environment of joining means [25] etc. A special attention is paid to resources of reinforced parts of glued-laminated timber, impossible to be evaluated $[21,22]$. Furthermore, attention is paid to concentrators of tension stress [25], breaking strain of elements $[26,27]$.

Intensive application of glulams [2] and their systems [1-3] attracts more attention to various aspects of their functioning [20, 28].

This has led to investigation of structures containing timber and some other material and their interaction
$[29,30]$. In order to come to adequate conclusions one should possess deep knowledge of interacting materials, eg concrete-timber-metal, concrete-timber, timber-gluemetal etc. This object of investigation (functioning of other materials used in glued-laminated timber) has reached an appropriate level [31-33]. It is worth to pay attention to functioning of timber together with materials the deformation modules of which greatly differ from that of glued-laminated timber. All the research work should be concentrated on practical application of interacting materials, such as glued-laminated timber-reinforcement [16, 34], glued-laminated timber-steel bars (implants) - glue [35], glued-laminated timber-reinforcing implants-glue-cement [36] etc.

Research shows that in the environment of implants distribution of their internal forces in matrix is uneven and this causes concentrations of tension stress. Depending on the structure of material receiving an implant, additional concentrations of tension stress may form. They are caused by layers existing in matrix, micro-, meso- and macrostructural defects, uneven adhesion of implant to matrix etc. When implants are screwed in, they may cause raised surfaces in matrix which are known as classic concentrators of tension stress. Results of comparatively similar tests have already been published [3436]. Nevertheless, some generalisations made are worth 
of deeper analysis and require further discussion on development of physical processes, their preconditions and consequences.

The above-mentioned tests continue to be in focus of attention. Screwed-in, glued-in and screwed-in-glued metal bars-implants working for extraction or sometimes for jacking are more and more widely used in mediumsize structures for joining timber elements in small hydrotechnic and similar constructions. Functioning of implanted bars is the object of investigation presented herein. This method of joining is quite reliable and technological. The process of preparation of connecting elements meets the requirements approved in modern industrial production.

Taking into consideration the above-mentioned facts the objective of the investigation carried out is to point out the most significant factors connected with extraction of implants. led:

For this purpose the following problems were tack-

1. As chemical and physical-mechanical properties of glue may essentially influence adhesion and strength of glulam surfaces, we investigated the action of some popular kinds of glues on functioning the implant and its limit state.

2. Considering a wide scale of structural anisotropy of wood and its response to external actions across and along layers, we investigated how the angle of screwingglueing into layers of timber influences the function of implant and the strength of inset.

3. Following the trends in modern research such as microand nano technologies of building materials, investigation of functioning of structural elements at micro level, attention was given to different types of disbonding of timber in the environment of implant and micro, meso and macroconcentrations of internal forces connected with them which are able to influence the functioning of the contact between an implant and timber.

\section{Tests}

According to the research programme of built-up beams, tests of connecting metal bars (implants) were carried out in Moscow (CNIISK) and later at the Dept of Civil Engineering of Šiauliai University and at the Dept of Building Structures of Kaunas University of Technology.

Some results of the research were included in the materials of conferences [35] and other publications.

Research on glued screwed-in metal bars (implants) in timber is necessary because work of such structures has not been sufficiently analysed and the data collected are fragmentary and at the level of linear empiric correlations.

That is why the objective of this work is to gain more information about physical-mechanical processes in the behaviour of implants.
The first series of tests was made to determine the force necessary to extract an implant out of a wooden prism and its dependence on the kind of glue used.

36 prism-shaped $140 \times 140 \times 300 \mathrm{~mm}$ and $140 \times 140 \times 900 \mathrm{~mm}$ test pieces were used. $20 \mathrm{~mm}$ diameter one meter thread bars made of high quality grade 45 structural steel were screwed into those prisms-test pieces (Fig 1). The screwing depth was equal to $10 \mathrm{di}-$ ameters of implant. Inclination of the bar axis in relation to timber fibre was $\alpha=0^{0}$ and $\alpha=30^{\circ}$. Test pieces were divided into 6 groups according to the type of glue used. A tiny groove along the total depth of screwed-in implant was cut to take away the surplus of glue. In such joints the bars transmit the greater part of the load through the adhesion of thread to timber $[34,35]$.

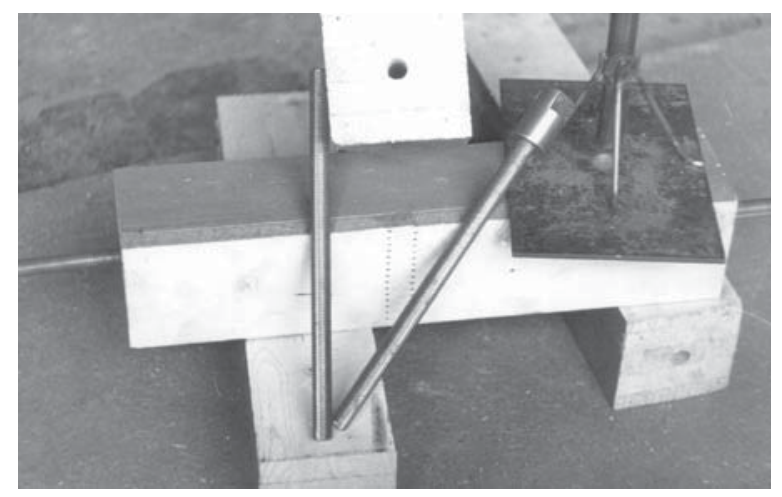

Fig 1. Means used in the experiment

The next series of tests was aimed at finding additional data and further analysis of the dependence of force needed for extracting the implant on the angle of screwing it into layers of timber. The angle of implant screwedin and the direction of timber layers varied at a wide range $0^{0} \leq \alpha \leq 90^{\circ}$.

45 pieces $(140 \times 140 \times 300 \mathrm{~mm})$ were tested to determine the force necessary to extract implants screwed-glued in at varying angles. $20 \mathrm{~mm}$ diameter $3 \mathrm{~mm}$ pitch one metre thread bars made of grade 45 construction steel were screwed into those prisms. We divided the test pieces into three groups according to the brand of glue used:

- control group (implants screwed in without glueing)

- implants screwed in and glued using phenolresorcine glue

- implants screwed in and glued using epoxy glue without filler.

The same details about tested specimens are presented in Table.

Wood of coniferous trees, laminated pine timber was used in tests. All specimens were cut from laminated beams. The beams were made of boards (33 mm thick) the dampness of which was up to $12 \%$. We selected this kind of timber because it is most widely applied in manufacturing laminated wood structures. Dampness of timber is selected according to working conditions. No other kinds of wood were used in the tests. 
Specimens for testing strength of implant-timber joints depending on the type of glue used

\begin{tabular}{|c|c|c|c|c|c|c|c|c|c|}
\hline \multirow[b]{2}{*}{ Series } & \multirow{2}{*}{$\begin{array}{l}\text { Dimensions } \\
b \times h \times l, \mathrm{~mm}\end{array}$} & \multirow{2}{*}{$\begin{array}{l}\text { Type of } \\
\text { glue }\end{array}$} & \multicolumn{5}{|c|}{ Implant } & \multirow{2}{*}{$\begin{array}{l}\text { Type } \\
\text { of } \\
\text { wood }\end{array}$} & \multirow{2}{*}{$\begin{array}{c}\text { Force of } \\
\text { extraction, } \\
\mathrm{kN}\end{array}$} \\
\hline & & & $\begin{array}{c}\text { angle of } \\
\text { screwing } \\
\alpha^{0}\end{array}$ & type & $\begin{array}{l}\text { diameter, } \\
\mathrm{mm}\end{array}$ & $\begin{array}{l}\text { screw } \\
\text { pitch, } \\
\mathrm{mm}\end{array}$ & $\begin{array}{l}\text { depth of } \\
\text { screwing, } \\
\text { mm }\end{array}$ & & \\
\hline A0 & $\begin{array}{l}140 \times 140 \times 300 \\
140 \times 140 \times 300 \\
140 \times 140 \times 300\end{array}$ & no glue & $\begin{array}{l}0 \\
0 \\
0\end{array}$ & $\begin{array}{c}\text { bar with spiral } \\
\text { ridge }\end{array}$ & $\begin{array}{l}20 \\
20 \\
20\end{array}$ & $\begin{array}{l}3 \\
3 \\
3\end{array}$ & $\begin{array}{l}200 \\
200 \\
200\end{array}$ & pine & $\begin{array}{l}50,0 \\
44,1 \\
36,2\end{array}$ \\
\hline A30 & $\begin{array}{l}140 \times 140 \times 300 \\
140 \times 140 \times 300 \\
140 \times 140 \times 300\end{array}$ & no glue & $\begin{array}{l}30 \\
30 \\
30 \\
\end{array}$ & $\begin{array}{l}\text { bar with spiral } \\
\text { ridge }\end{array}$ & $\begin{array}{l}20 \\
20 \\
20\end{array}$ & $\begin{array}{l}3 \\
3 \\
3\end{array}$ & $\begin{array}{l}200 \\
200 \\
200\end{array}$ & pine & $\begin{array}{l}44,3 \\
54,1 \\
56,5\end{array}$ \\
\hline B0 & $\begin{array}{l}140 \times 140 \times 300 \\
140 \times 140 \times 300 \\
140 \times 140 \times 300\end{array}$ & $\begin{array}{l}\text { phenol- } \\
\text { resorcin }\end{array}$ & $\begin{array}{l}0 \\
0 \\
0\end{array}$ & $\begin{array}{l}\text { bar with spiral } \\
\text { ridge }\end{array}$ & $\begin{array}{l}20 \\
20 \\
20\end{array}$ & $\begin{array}{l}3 \\
3 \\
3\end{array}$ & $\begin{array}{l}200 \\
200 \\
200\end{array}$ & pine & $\begin{array}{l}69,2 \\
74,1 \\
60,4\end{array}$ \\
\hline B30 & $\begin{array}{l}140 \times 140 \times 300 \\
140 \times 140 \times 300 \\
140 \times 140 \times 300\end{array}$ & $\begin{array}{l}\text { phenol- } \\
\text { resorcin }\end{array}$ & $\begin{array}{l}30 \\
30 \\
30\end{array}$ & $\begin{array}{l}\text { bar with spiral } \\
\text { ridge }\end{array}$ & $\begin{array}{l}20 \\
20 \\
20\end{array}$ & $\begin{array}{l}3 \\
3 \\
3\end{array}$ & $\begin{array}{l}200 \\
200 \\
200\end{array}$ & pine & $\begin{array}{l}100,0 \\
96,1 \\
99,3\end{array}$ \\
\hline $\mathrm{C} 0$ & $\begin{array}{l}140 \times 140 \times 300 \\
140 \times 140 \times 300 \\
140 \times 140 \times 300\end{array}$ & $\begin{array}{c}\text { modified } \\
\text { phenol- } \\
\text { resorcin }\end{array}$ & $\begin{array}{l}0 \\
0 \\
0 \\
\end{array}$ & $\begin{array}{l}\text { bar with spiral } \\
\text { ridge }\end{array}$ & $\begin{array}{l}20 \\
20 \\
20 \\
\end{array}$ & $\begin{array}{l}3 \\
3 \\
3 \\
\end{array}$ & $\begin{array}{l}200 \\
200 \\
200 \\
\end{array}$ & pine & $\begin{array}{l}70,2 \\
60,3 \\
80,1 \\
\end{array}$ \\
\hline C30 & $\begin{array}{l}140 \times 140 \times 300 \\
140 \times 140 \times 300 \\
140 \times 140 \times 300\end{array}$ & $\begin{array}{c}\text { modified } \\
\text { phenol- } \\
\text { resorcin }\end{array}$ & $\begin{array}{l}30 \\
30 \\
30\end{array}$ & $\begin{array}{l}\text { bar with spiral } \\
\text { ridge }\end{array}$ & $\begin{array}{l}20 \\
20 \\
20\end{array}$ & $\begin{array}{l}3 \\
3 \\
3\end{array}$ & $\begin{array}{l}200 \\
200 \\
200\end{array}$ & pine & $\begin{array}{c}104,1 \\
92,3 \\
92,1\end{array}$ \\
\hline D0 & $\begin{array}{l}140 \times 140 \times 300 \\
140 \times 140 \times 300 \\
140 \times 140 \times 300\end{array}$ & epoxy & $\begin{array}{l}0 \\
0 \\
0\end{array}$ & $\begin{array}{l}\text { bar with spiral } \\
\text { ridge }\end{array}$ & $\begin{array}{l}20 \\
20 \\
20\end{array}$ & $\begin{array}{l}3 \\
3 \\
3 \\
\end{array}$ & $\begin{array}{l}200 \\
200 \\
200\end{array}$ & pine & $\begin{array}{l}83,2 \\
86,1 \\
78,0\end{array}$ \\
\hline D30 & $\begin{array}{l}140 \times 140 \times 300 \\
140 \times 140 \times 300 \\
140 \times 140 \times 300\end{array}$ & epoxy & $\begin{array}{l}30 \\
30 \\
30\end{array}$ & $\begin{array}{l}\text { bar with spiral } \\
\text { ridge }\end{array}$ & $\begin{array}{l}20 \\
20 \\
20\end{array}$ & $\begin{array}{l}3 \\
3 \\
3\end{array}$ & $\begin{array}{l}200 \\
200 \\
200\end{array}$ & pine & $\begin{array}{l}124,0 \\
104,5 \\
112,6\end{array}$ \\
\hline E0 & $\begin{array}{l}140 \times 140 \times 300 \\
140 \times 140 \times 300 \\
140 \times 140 \times 300\end{array}$ & epoxy & $\begin{array}{l}0 \\
0 \\
0\end{array}$ & $\begin{array}{l}\text { reinforcement } \\
\text { A-III Ø18 }\end{array}$ & $\begin{array}{l}18 \\
18 \\
18\end{array}$ & $\begin{array}{l}- \\
- \\
-\end{array}$ & $\begin{array}{l}200 \\
200 \\
200\end{array}$ & pine & $\begin{array}{c}100,2 \\
98,5 \\
102,1\end{array}$ \\
\hline E30 & $\begin{array}{l}140 \times 140 \times 300 \\
140 \times 140 \times 300 \\
140 \times 140 \times 300\end{array}$ & epoxy & $\begin{array}{l}30 \\
30 \\
30\end{array}$ & $\begin{array}{l}\text { reinforcement } \\
\text { A-III Ø18 }\end{array}$ & $\begin{array}{l}18 \\
18 \\
18\end{array}$ & $\begin{array}{l}- \\
- \\
-\end{array}$ & $\begin{array}{l}200 \\
200 \\
200\end{array}$ & pine & $\begin{array}{l}134,0 \\
116,3 \\
123,1\end{array}$ \\
\hline F0 & $\begin{array}{l}140 \times 140 \times 300 \\
140 \times 140 \times 300 \\
140 \times 140 \times 300\end{array}$ & hermetic & $\begin{array}{l}0 \\
0 \\
0\end{array}$ & $\begin{array}{c}\text { bar with spiral } \\
\text { ridge }\end{array}$ & $\begin{array}{l}20 \\
20 \\
20\end{array}$ & $\begin{array}{l}3 \\
3 \\
3\end{array}$ & $\begin{array}{l}200 \\
200 \\
200\end{array}$ & pine & $\begin{array}{l}37,1 \\
44,2 \\
42,0\end{array}$ \\
\hline F30 & $\begin{array}{l}140 \times 140 \times 300 \\
140 \times 140 \times 300 \\
140 \times 140 \times 300\end{array}$ & hermetic & $\begin{array}{l}30 \\
30 \\
30\end{array}$ & $\begin{array}{l}\text { bar with spiral } \\
\text { ridge }\end{array}$ & $\begin{array}{l}20 \\
20 \\
20\end{array}$ & $\begin{array}{l}3 \\
3 \\
3\end{array}$ & $\begin{array}{l}200 \\
200 \\
200\end{array}$ & pine & $\begin{array}{l}49,0 \\
48,5 \\
50,0\end{array}$ \\
\hline
\end{tabular}

For glueing in implants we used industrialised production glues, which are widely applied in manufacturing laminated structures in mass production and assembling parts. Carrying out the tests we tried to meet the needs of builders imitating situations they face in practice.

Chemical structure of glue was not investigated, because working standards governmental documents-strictly regulate and ensure it.

Resistance of implants to extraction was tested using GMS-50 (Fig 2). In the first series of tests the load was increased in steps ( 1 step $=6 \mathrm{kN}$ ) with the exception of test pieces in groups $\mathrm{I}$ and $\mathrm{V}$ where the steps of increasing the load were equal to $10 \mathrm{kN}$. We measured extraction of bars using clock-type indicators.

\section{Results}

Having carried out the tests we drew the conclusion that type of glue used greatly influences the functioning of an implant. The influence of glue is especially obvious when steel bars-implants are screwed in at an angle of $\alpha=30^{0}$ in relation to timber fibre. When $\alpha=0^{0}$ adhesion of implant to timber is not sufficiently deep (Fig 3).

In this case quite frequently the implant thread damages the longitudinal fibres of timber-structural reinforcement in the contact zone. The extent to which a screwedglued in implant resists extracting it out of prism depends on the size of glued surfaces. Micro concentrations of tensile stress may occur around timber fibres in 


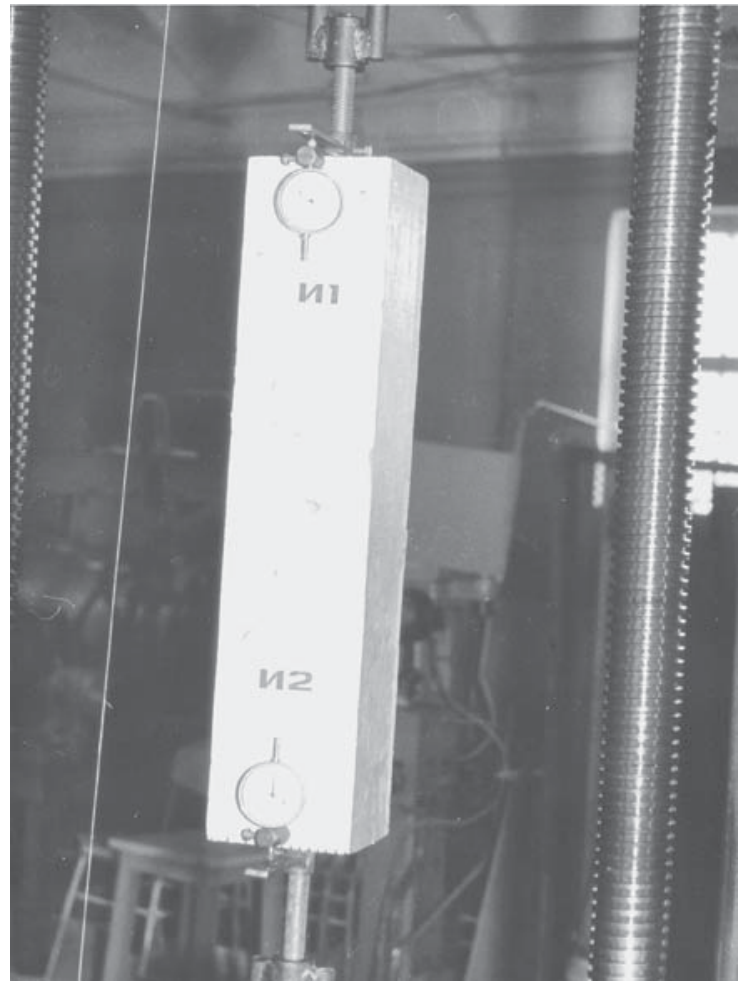

Fig 2. Performance of the test

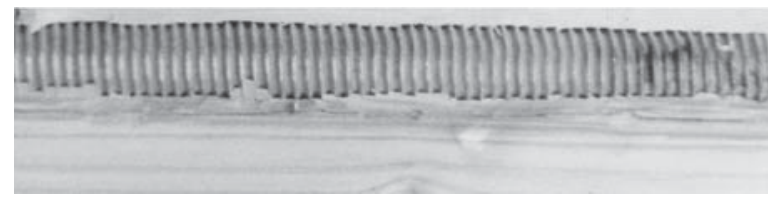

Fig 3. Adhesion of implant thread to timber when angle of screw $\alpha=0^{\circ}$

the same way as in other reinforced structures when timber elements are exposed to external influence. They affect the process of forming damages in its initial stage and implant-timber interaction.

The fracture at the joint of steel bar-implant with timber is presented in Fig 4.

The strength of bar-implants is considerably higher than that of timber (the difference equals at least one grade). The stage of breaking strain process is considered to be functioning of a bar-implant at limit state. In this case pressure decreases suddenly in the loading imitating system (limit state I) and implant deformations increase rapidly causing breaking strain at timber-implant contact (limit state II).

Resistance of screwed-glued in implants of extraction may grow considerably depending on adhesion of glue to a timber prism as well as on quality of implant metal. In addition, the glue serves as a means of softening and even embedding of microconcentrators of defects.

For example, micro and nano technologies applied to various types of concrete reveal that embedding of

$$
\alpha=0^{\circ}
$$

a)

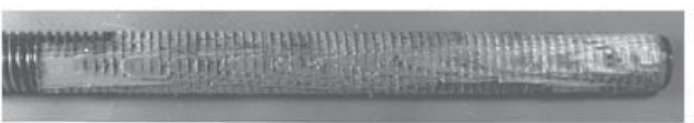

b)

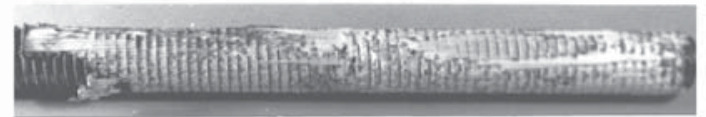

c)

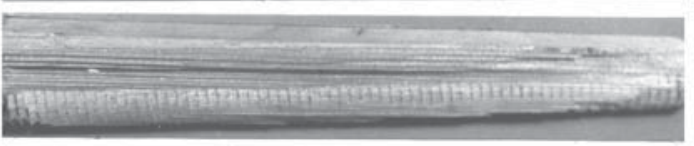

d)

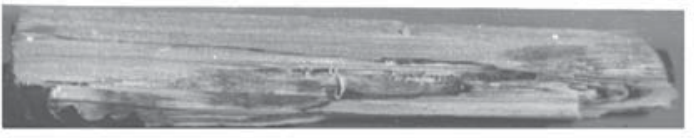

e)

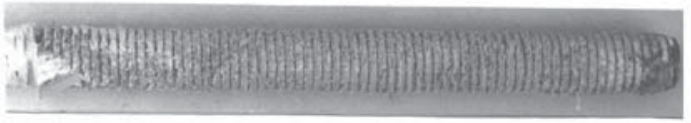

$\alpha=30^{\circ}$

f)

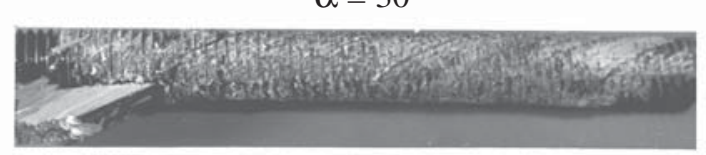

g)

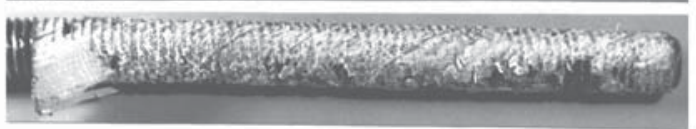

h)

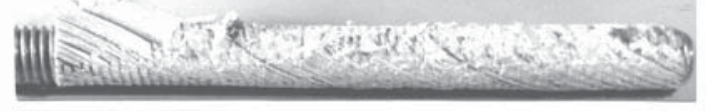

i)

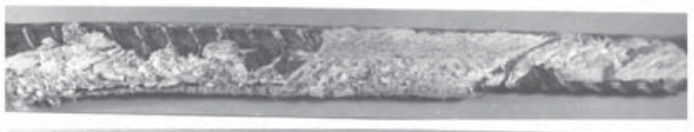

j)



Fig 4. Examples of how fracture of contact between barimplants and timber depends on angle a and type of glue. Here the implant is fixed: $\mathrm{a}, \mathrm{f}$ - screwed-glued by phenolresorcin glue; b, g - screwed-glued by modified phenolresorcin glue; c, h- screwed-glued by epoxy glue; $\mathrm{d}, \mathrm{i}-$ glued deformed reinforcement explant (A-III Ø18) using epoxy glue; e, $\mathrm{j}$ screwed-glued in a hermetic seal

sharp-shape defects with plasticisers may increase the strength of jointing medium which has been weakened by microconcentrators rup to 1,5 times and more [6]. Using epoxy glue the strength of adhesion of screwedglued in implant to timber increases by 1,9-2,2 times in comparison with control group where it is screwed wihout using glue and merely $12-18 \%$ in comparison with the case when the implant is screwed-glued by phenol-resorcin glue.

Experimental data concerning the strength of extraction force $F$ and interrelationship of deformations at the contact between the implant and timber for variously implanted bars is presented in Fig 5 (when the angle between the implant and timber layers $\alpha=0^{\circ}$ (a) and $\left.\alpha=30^{\circ}(\mathrm{b})\right)$. 

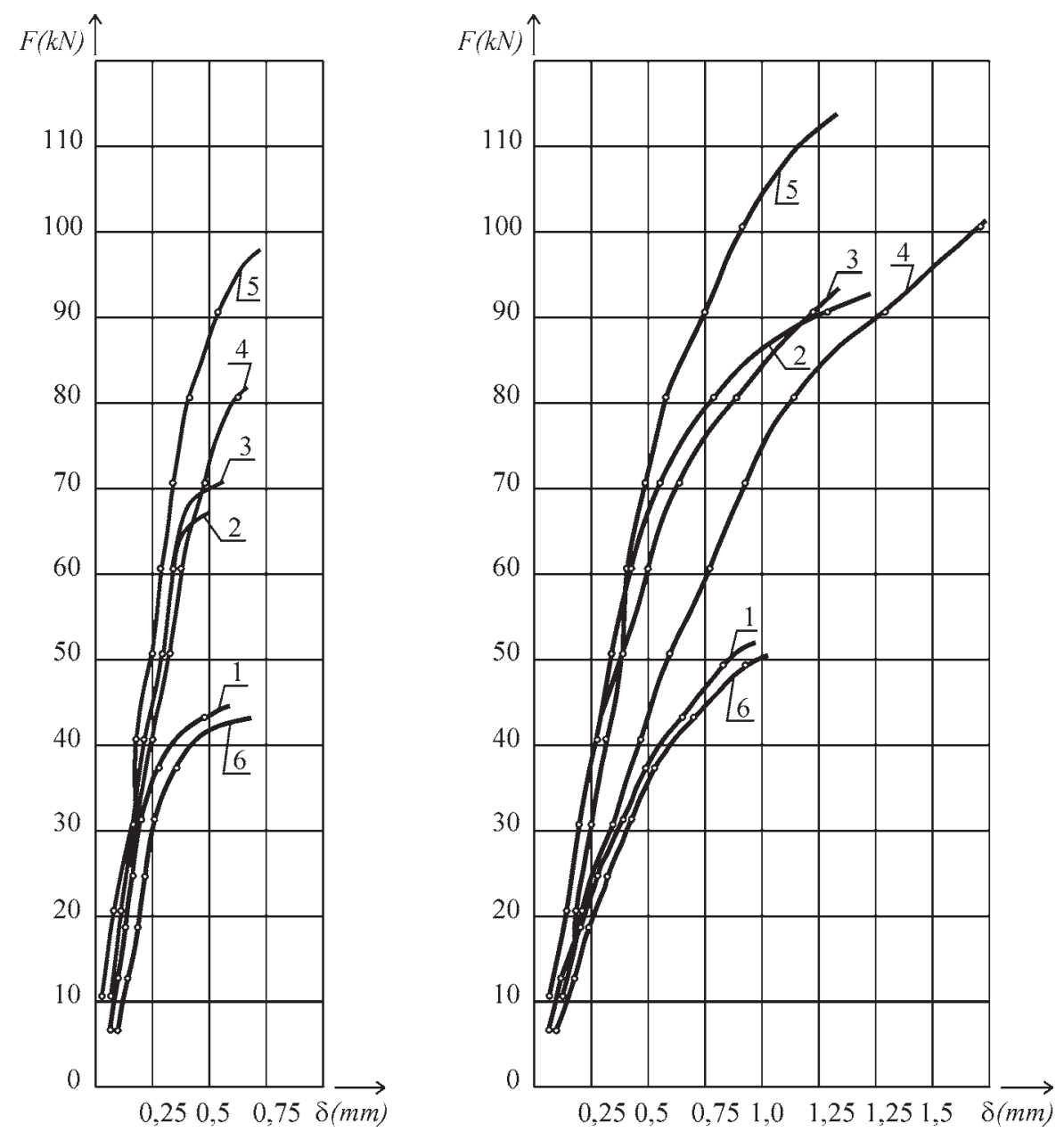

Fig 5. Forces necessary for extracting an implant-dependence of deformations on the angle of fixing it, when the angle between the implant and the timber layers is $\alpha=0^{\circ}$ (a) and $\alpha=30^{\circ}$ (b) and is fixed by: 1) screwing in without using glue; 2) screwing-glueing by phenol-resorcin glue; 3) screwing-glueing by modified phenol-resorcin glue; 4) screwing-glueing by epoxy glue; 5) glueing deformed reinforcement implant (A-III Ø18) by epoxy glue; 6) screwing and glueing in a hermetic seal

Some of the types of glue penetrate timber to the necessary extent (Fig 6). The glue fills all cavities, cracks and other defects in timber sufficiently well. However, resistance to extracting of implant using various types of glue increases insignificantly. Thus embedding of microconcentrators itself cannot increase the interaction of timber and metal implant considerably. An example supporting the above-mentioned fact is the test where a silicate hermetical seal is used to join an implant with

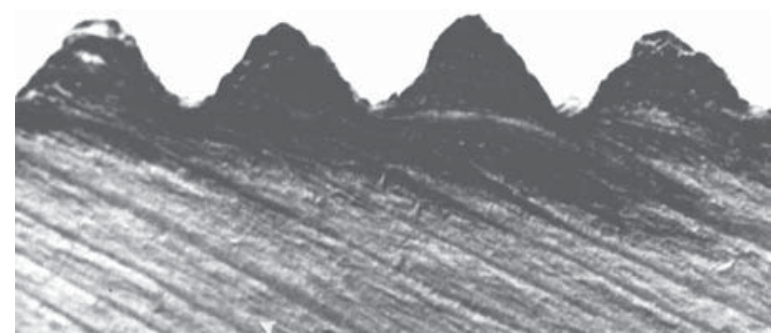

Fig 6. Penetrating of phenol-resorcin glue into timber when thread angle $\alpha=30^{\circ}$ timber. In this case the strain module is relatively small. That is why it actually fails to carry load. However, glue fills the cavities in timber, defects made in the process of screwing etc. Thus timber itself is strengthened and it softens the process of deformation when the implant is being extracted.

The wooden prisms used in the test were comparatively small in size. Diameter of implant thread was in fact not much larger than the net cross-section of the part of the bar which was screwed in. So the concentration of tensile deformations in the environment of implant developed in a comparatively small area (in proportion to the size of test piece and the implant).

As we have mentioned above, the glue fills a part of disturbances and binds a considerable part of spalls and fibres damaged in the process of screwing. However, in case of screwed-glued in implant tested here there is in fact no surplus of glue (pressure) in the environment. The glue is not able to fill the damages which occurred at the surface of implant-timber contact, espe- 
cially those in weaker layers of timber. Spalls in stronger timber layers are not all glued properly. Using popular glue one cannot achieve the same effect as using special glues which are usual in micro and especially nano [6] technologies.

Ejecting sufficiently liquid glue under pressure its effect on strength of contact between screwed-glued in implant and timber might be greater. Cavities in timber around the contact could be filled more properly and spalls could serve as reinforcement as in a timber-woolcement slab.

The first series of tests proved that the implant-timber contact undergoes brittle (quasi-brittle) failure. This is typical in case when the screwing angle is $\alpha=0$ or close to it. Extraction process is connected with greater non-linear (Fig 5) plastic or quasi-brittle deformations when $\alpha \geq 30^{\circ}$. In this case the non-linear relationship $F-\delta$ depends on accumulation of microdefects, as plastic deformations both of timber and glue are comparatively small. They are more significant in the initial stages of breaking strain. Thus limit states of an object and non-linear relationship $F-\delta$ are usually determined by accumulations of microdefects which merge to form macrodefects.

The force necessary to extract implants glued in deformed reinforcement bars out of their nests in timber is by $10-18 \%$ greater than that of screwed-glued in bars. The explanation why it is so can be the larger failure surface. After extracting a deformed reinforcement implant the hole has a larger diameter than that after extracting a screwed-in implant. Using deformed reinforcement bars increases the area of adhesion surface. In this case extracting the implant destroys a part of timber in its environment which is stuck to uneven parts of implant by means of glue. Calculation of nominal stress

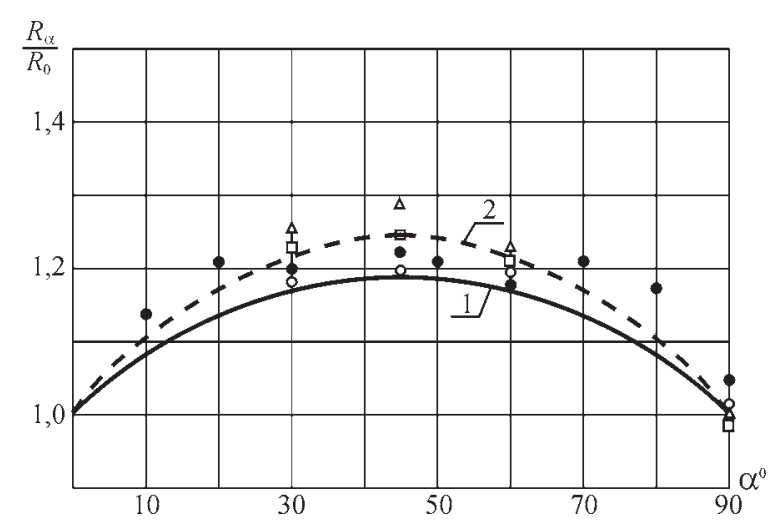

Fig 7. To form a unit of area of a new surface part of force (of nominal stress) necessary depends on the way how the implant is inserted and on the angle the implant makes $0^{0} \leq \alpha \leq 90^{\circ}$ to the direction of timber layers, when: o - implant bars are screwed in without glue; $\square-$ implants screwed-glued by epoxid glue; $\triangle-$ implants screwed and glued by phenol resorcin glue; $\bullet$ deformed reinforcement bars are glued into nests prepared in advance. Here: curve $1-\mathrm{a}$ is technically reliable, when $c=0,4[\mathrm{MPa}]$; curve 2-a, when average value of constant is $c=0,5[\mathrm{MPa}]$ per unit of area of newly formed surface the values obtained differ from analogous stresses calculated after extracting a screwed-glued in implant merely by $5 \%$ (Fig 7).

It is not easy to explain all peculiarities connected with resistance of implants to extraction considering only principles of fracture mechanics, for example, calculating power consumption used to form a unit of area in the new surface. The process of breakage at the end of which the implant is extracted ultimately is not continuous. It can be considered to be quasi-brittle containing continuous stages of breaking strain and discretion operations. Uneven distribution of tension stresses along the surface of contact of implant with timber at the initial stage of continuous deformations can prove this (Fig 8).

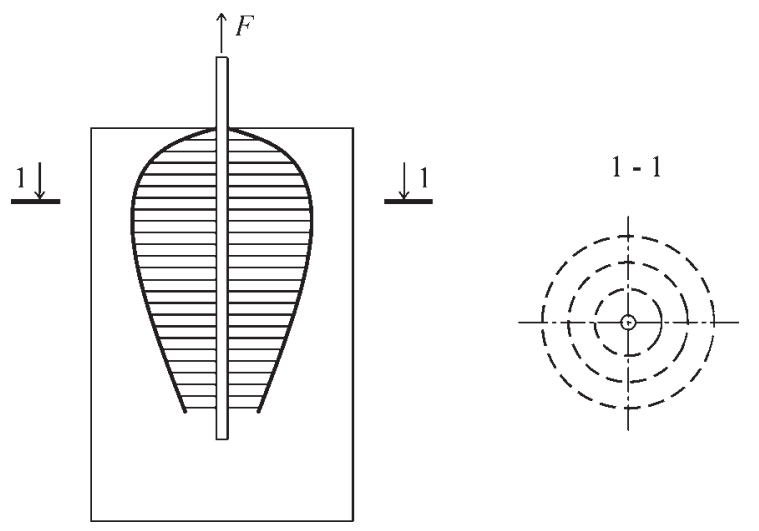

Fig 8. Diagrams of concentrations of tension stresses around the implant in longitudinal and latitudinal crosssections of a prism

Increasing the load tensile stresses and deformations gradually equalise due to local discretions and other different microprocesses in the zone of action. Another fact supporting this idea is that the nominal part of extraction force $R_{\alpha}$, necessary in forming an area unit of the new surface, depends on the angle at which the implant is screwed in $(\alpha)$ Dependence

$$
R_{\alpha}=R_{0}+c \sin \alpha \cos \alpha,
$$

is used to approximate experimental relation of this value to angle $\alpha$, at which the bar is screwed-glued into timber layers.

Here $R_{0}$ - a part of force necessary to extract the implant calculated per a newly formed area unit, when screwing angle $\alpha=0^{0}$.

In case of experiment described the average value of constant is $c=0,5[\mathrm{MPa}]$ (Fig 7, curve 2-a). When $c=0,4 \quad[\mathrm{MPa}]$, a technically reliable curve is obtained (Fig 7, curve 1-a). The force necessary to extract the screwed-glued in implant increases with the increase of angle between the screw and timber fibres $0^{0} \leq \alpha \leq 45^{\circ}$. The value decreases when angle a increases at interval $45^{0} \leq \alpha \leq 90^{\circ}$. At the interval $40^{0} \leq \alpha \leq 50^{\circ}$ derivative of force approximately equals 0 . Therefore the depen- 


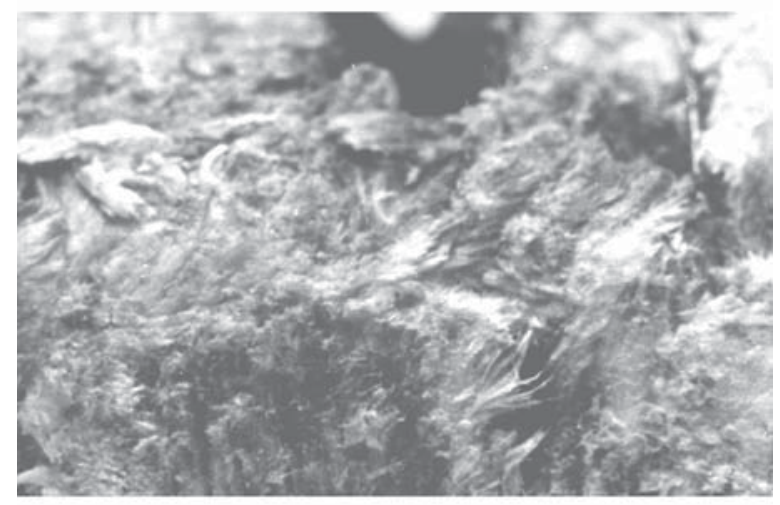

Fig 9. Quasi-brittle destruction of contact when timber fibres have been bent

dence of the force necessary to extract the implant on the angle a can be maximised on the basis of empiric data using a definite sort of glue and a particular method of fixing the implant.

With the increase of angle a the character of destruction of contact between implant and timber changes significantly. Destruction of contact at the interval appeared to be typically quasi brittle. Timber fibres through which the implant had been screwed in were bent back in the direction of extraction force and torn to pieces (Fig 9).

In case when $\alpha$ was close to $0^{\circ}$ or $90^{\circ}$ the process of failure was more brittle, the surfaces of contact breakage were rather smooth, torn to a smaller extent.

At the end we came to the conclusion that this problem could be vitally important in a wider context of constructive tasks. It can be also connected with the analysis of behaviour of constructional materials and motivated interpretation of consequences. Thus, for constructional purposes a reinforcing bar or some of them are implanted into a matrix such as concrete, plastic, timber, sometimes even metal. Elements used to join different structures are engaged in a similar way. New ways of solutions in engineering, where implants are used both as connecting and reinforcing elements have been developed recently. In these cases the implants have been used to increase the strength of constructional elements as well as their rigidity. In all above-mentioned cases there are concentrations of tension strains at micro, submicro and macro levels. These concentrations greatly effect the work of structures.

Research work presented here matches the strategy of working-out and improving structures contemporarily popular in Europe, especially such as large-opening glued laminated timber. For example, international organisation GLULAM [37] formulates its strategy in the following way: "Laminated timber has been recognised for a long time as a most appropriate basic material for our design and construction tasks. It corresponds to an algebra of constructions additive, associative and communicative. It also fulfills for our survival the necessary condition of durability."
That is why glued laminated structures should be tested and more widely used.

\section{Conclusions}

1. The tests show that the type of glue used is relatively a more important factor for the angle at which the implant is screwed $\alpha=0^{0}$ (the screw goes along timber fibres). At such contacts adhesion of thread to timber is not so deep. Timber fibres in the direct environment of the implant are damaged in the process of screwing. Therefore the quality of adhesion of glue to timber and metal is vitally important.

2. The glue with a relatively small (in comparison with timber) modulus of deformation in fact does not take over the load. Therefore the strength of contact implant-timber does not increase, deformability is great, reliability is doubtful.

3. Even the glue having good adhesion does not effect such properties as short-term resistance to extraction of screwed-glued in implants.

4. Extraction of implants screwed in along timber fibre (fracture of contact with timber) when $\alpha=0^{0}$ is far more brittle. Plastic, time-dependent and quasibrittle residual deformations are slight. Strength of contact depends very much on the quality of glueing in the implant.

5. The best adhesion between the thread and timber is obtained when implants are screwed in at $40^{0} \leq \alpha \leq 50^{0}$. In this case the choice of glue does not affect the result very much. In this case, however, functioning of implant is connected with considerable residual deformations (time-dependent deformations in timber and quasibrittle limit failure). What concerns formation of limit states implants screwed in at an angle are deformable to a great extent. In these cases their functional limits according to the second limit state are very significant.

\section{References}

1. Valentinavičius, A. and Valiūnas, B. Timber structures (Medinès konstrukcijos). Vilnius: Enciklopedija, 2000. 222 p. (in Lithuanian).

2. Morkevičius, A. and Papreckis, B. Timber and goods from timber (Mediena ir jos gaminiai). Vilnius: Senoja, 2004. 238 p. (in Lithuanian).

3. Ivanov, V. A. et al. Timber and plastic structures (Конструкции из дерева и пластмасс). Kiev: Budivelnik, 1970. 504 p. (in Russian).

4. Kocegubov, V. P. et al. Glued timber and plastic structures. Joint higher schools tematic collection (Конструкции из клееной древесины и пластмасс. Межвузовский тематический сборник). Leningrad: Publ. LISI, 1984. 145 p. (in Russian).

5. Maksimovich, B. G. Design and manufacturing of glued timber structures (Проектирование и производство конструкций из клееной древесины). Minsk: Publ. Vischa shkola, 1981. 212 p. (in Russian). 
6. Kocegubov, V. P. et al. Raising of durability and reliability of timber and plastic building structures (Повышение долговечности и надежности строительных конструкций из дерева и пластмасc). Leningrad: Publ. LISI, 1987. 80 p. (in Russian).

7. Kovaltchuk, L. M.; Mishelova, G. N.; Strelcov, D. J. and Nikulichina, R. V. Estimation of technical state of timber structures at long time service. Building materials (Строительные материалы), № 5, 2003, p. 22-24 (in Russian).

8. Smortchkov, A. A.; Delova, M. U.; Schedrin, A. N. and Smortchkov, D. A. Physical and technical basis of estimation of reliability at service of glued timber structures. In: Proc of 32nd Allrussian scientific and technical conference: Urgent problems of building to-day (Сборник материалов 32-й Всероссийской научно-технической конференции „Актуальные проблемы современного строительства“), Part. 2, Penza: Publ, PGASA, 2003, p. 103-105 (in Russian).

9. Smorchkov, A. A.; Delova, M. I. and Schedrin, A. N. Pecularities of stress-strain-deformation state of glued timber structures. In: Proc of 3rd Allrussian scientific and technical conference: Innovations in architecture, design of building structures and reconstruction (Сборник материалов 3-й Всероссийской научно-технической конференции „Новое в архитектуре, проектировании строительных конструкций и реконструкции“), Vol 1, Cheboksary: Publ. Chuv. Un, 2001, p. 100-104 (in Russian).

10. Dmitriev, P. A. and Mikhailenko, O. A. On working and calculation of support units in a timber-metal three-angle trusses without slanting members. Building construction (Строительство), No 1, 2003, p. 4-9 (in Russian).

11. Seliutina, L. T. and Krilova, O. I. Peculiarities of design of junctions, based on cogged metal plates. In: Materials of interregional scientific and practical conference (Материалы межрегиональной научно-практической конференции Брянск, 19-20 апреля 2001 г.). Briansk: Publ. BGITA, 2002, p. 132-134 (in Russian).

12. Povetkin, S. V. Resistivity of a bending timber glued structures to dinamic loading. In: Vibrating machines and technologies „Vibration 2001“ (Вибрационные машины и технологии „Вибрация 2001“). Prac. of Kursk State technological university, 2001, p. 173-176 (in Russian).

13. Cherniak, A. M. et al. Investigations in building mechanics and building structures (Исследования по строительной механике и строительным конструкциям). Tomsk, 1987. 256 p. (in Russian).

14. Iljin, V. P. et al. Problems of mechanics of building structures and materials. Inter higher school tematic collection of works (Вопросы механики строительных конструкций и материалов. Межвузовский тематический сборник трудов). Leningrad: Publ. LISI, 1987. 98 p. (in Russian).

15. Dmitrijev, P. A. and Lebedev, G. B. On regulation of strains into complex building structures. Building construction (Строительство), No 10, 2002, p. 120-124 (in Russian).

16. Navalush, K. J. and Tkachenko, O. A. Reinforced timber structures and methods of their design. In: 60th regional scientific and practical conference (60-я региональная научно-практическая конференция). Chabarovsk: Publ. DVGUPS, 2002, p. 94-96 (in Russian).

17. Beliankin, M. I. Conception of deformation model of structures and elements. Building construction (Строительство), No 4, 2003, p. 34-39 (in Russian).

18. Serov, E. N. Recommendations to perfection of timber structures design norms. Building construction (Строительство), No 4, 2003, p. 9-16 (in Russian).

19. Jagniuk, B. N. Theoretical basis for design of timber structures according to norms of European Union - Eurocode 5 (Теоретические основы проектирования деревянных конструкций по нормам Европейского Союза Еврокоду 5). Petrozavodsk: Publ. Petr. PU, 2002. 139 p. (in Russian).

20. Čechavičius, R. Slip of "Bulldog"-type toothed-plate connectors in steel-timber joints of open-web girders. Journal of Civil Engineering and Management, Vol X, Suppl 1. Vilnius: Technika, 2004, p. 23-29.

21, Radford, D. W.; Van Goethem, D.; Gutkowski, R. M. and Peterson, M. L. Composite repair of timber structures. Construction and Building Materials. Vol 16, No 7, 2002, p. 417-425.

22. Stasevich, N. J. and Tkachenko, O. A. Investigations in strength capacity of glued small diameter strips of reinforcement. In: 60th regional scientific and practical conference (60-я региональная научно-практическая конференция). Chabarovsk, Apr 10-11, 2002. Proc of conference. Part 2, 2002, p. 94-96 (in Russian).

23. Tkachenko, O. A. and Zeleznikov, V. A. Research of compound beams formed by square timbers with glued in steel bars joint. An investigation of work and perfection of methods for calculation of buildings and erection structures (Исследование работы и совершенствование методов расчета строительных конструкций зданий и сооружений). Higher schools collection of scientific works. Far-Eastern state university of railway traffic. Chabarovsk: Publ. DVGUPS, 2001, p. 11-18 (in Russian).

24. Volkov, A. A.; Ermakov, H. H.; Mizenin, M. V. and Tkachenko, O. A. Experimental research of compound timber beams formed by square timber with glued in steel bars. In: Proc of the 58th scientific conference: Scientific, technical and economical problems of transport (Научнотехнические и экономические проблемы транспорта. Материалы 58-й научной конференции). Chabarovsk, 2000, Part 2, Publ. DVGUPS, p. 107-108 (in Russian).

25. Chausov, N. G.; Lebedev, A. A. and Bogdanovich, A. Z. On a limit damage in the concentrators surrounding. Problems of strength (Проблемы прочности), № 6, 2002, p. 31-37 (in Russian).

26. Strelcov, D. J. and Tarasov, M. A. Impact of crack on stress state of timber beams. Transactions of higher schools. Forestry journal (Известия вузов. Лесной журнал), 2003, No 2-3, p. 27-34 (in Russian).

27. Petrunina, E. A. On a possibility to use a model with local damages. Problems of durability of structural elements under the impact of loading and service conditions. Higher schools scientific collection (Проблемы прочности элементов конструкций под действием нагрузок и рабочих сред. Межвузовский научный сборник). Saratov: Publ. SGTU, 2002, p. 47-53 (in Russian). 
28. Savich, V. S. and Sirota, J. J. European methods for steadfast testing of glued joints and choice of glues for timber structures. Building materials (Строительные материалы), No 5, 2003, p. 12-13 (in Russian).

29. Gurkšnys, K. and Kvedaras, A. Experimental results of timber-concrete composite embedded connection. In: Progressive building (Pažangioji statyba). Kaunas: Technologija, 2004, p. 52-57 (in Lithuanian).

30. Motak, J. and Machacek, J. Experimental behaviour of composite girders with steel undulating web and thin-walled shear connectors Hilti Stripcon. Journal of Civil Engineering and Management, Vol X, No 1. Vilnius: Technika, 2004, p. 45-49.

31, Marchuk, V. Dispersibility of the silica fume slurry in cement paste and mortar. Concrete, No 7-8, 2002, p. 393398.

32. Fugian, Y. Effect of adsorption on nano indentation test. Applied Physics Letters, No 6, 2002, p. 959-961.
33. Isao, T.; Masumi, K. and Kunio, C. A study on the process for formation of spherical cement through an examination of the changes of powder properties and electrical charges of the cement and its constituent materials during surface modification. Cement and Concrete Researches, Vol 32, No 1, 2002, p. 57-64.

34. Riberholt, H. Glued steel bolts for glulam. Building Research and Practice (Batiment international), 1980, Vol 8, No 3, p. 146-157 (in French).

35. Roličius, J. Strength of slanting glued in timber joint. In: Materials of scientific conference „Building materials and goods“ (Mokslinès konferencijos „Statybinès medžiagos ir gaminiai“ pranešimų medžiaga). Kaunas: Technologija, 1993, p. 181-183 (in Lithuanian).

36. Roličius, J. Strength of timber joints with glued and screwed into bars. In: Proc of conference „Building construction and building industry“. (Konferencijos „Statyba ir statybos pramonè" pranešimų medžiaga). Kaunas: Technologija, 1995, p. 200-203 (in Lithuanian).

37. Stingl, H. GLULAM award. Wien, 1999. 20 p.

\section{DEFORMACIJŲ KONCENTRACIJOS IMPLANTUOTO STRYPO APLINKOJE IR JŲ NATŪRINIAI TYRIMAI}

\section{Keras, J. Roličius}

Santrauka

Betonuose, plastike, medienoje ar panašioje medžiagoje - matricoje konstrukciniais sumetimais dažnai yra įterpiami stipresnès medžiagos strypai - armuojantys implantai. Tobulinami inžineriniai kompleksinio implantų naudojimo sprendimai, kai jie naudojami ir kaip armavimo, ir kaip jungimo priemonès. Tačiau iki šiol sukaupti implantų darbo tyrimų duomenys nèra išsamūs, jų apibendrinimai - kiek skuboti.

Tęsiant šiuos tyrimus, buvo bandomi įsriegti ir iklijuoti ar tik įklijuoti i pušinę medieną stambieji metrinio sriegio strypai-implantai. Buvo keičiamas implanto su medienos sluoksniais sudaromas kampas, klijų pobūdis, kiti veiksniai. Buvo aprašytos stiprumo, deformatyvumo, irimo charakteristikos, nagrinėtu procesų pobūdis. Pasiūlytos empirinės pareinamybės: vidutinè, gauta, remiantis bandymų duomenimis, techniškai patikima šių duomenų aibeje ir pan.

Raktažodžiai: mediena, implantai, klijai, stiprumas, deformatyvumas, irimas.

Valerijus KERAS. Doctor, Associate Professor in technical sciences, Associate Professor in social sciences. Present position: Associate Professor at the Dept of Building Structures, Kaunas University of Technology. Research interests: building structures, structural mechanics, fracture mechanics (problems of concentration of stress and strains), durability, imitation of destructions. Publications: about 129 articles and theses on stress concentration, strength, fracture of structures, research management.

Jonas ROLIČIUS. Lecturer at the Dept of Civil Engineering, Šiauliai University. Fields of scientific research involve tensioning deformation and strength constructions loaded with small areas. 28 published articles and theses for scientific conferences on the above-mentioned research problems. 